It fills a gap, and while the word definitive is overused, in this case it applies.

\title{
UNIVERSITY OF NORTHERN IOWA
}

William H. GRAVES

American Indians, American Justice, by Vine Deloria, Jr. and Clifford M. Lytle. Austin: University of Texas Press, 1983. xiii, 246 pp. Bibliography, index. $\$ 9.95$ paper.

In American Indians, American Justice, Vine Deloria and Clifford M. Lytle have attempted to describe traditional Native American governmental patterns and methods of justice, and to trace the impact of Anglo-American political ideas on these Indian systems. In the process, the authors have accurately defined the legal position of Indians within the framework of the American political and judicial experience.

Deloria and Lytle begin their book with a discussion of the nature of federal-Indian relations. Building on the legal precedent first enunciated by United States Supreme Court Chief Justice John Marshall in Worcester v. Georgia as well as ideas mentioned in Behind the Trail of Broken Treaties, an earlier work of Deloria's, the authors depict this relationship as one in which the Indian tribes assumed the role of wards, or in the words of Marshall, "domestic dependent nations," over which the United States government exercises limited legal control. Deloria and Lytle then carefully note frequent instances when the federal government has exceeded what the authors regard as the limits of its constitutional power over Indian tribes as set forth by Marshall. According to the authors, white men have unnecessarily insisted that Native Americans adopt European concepts of government and jurisprudence. Nevertheless, Deloria and Lytle note that Indian tribes have adjusted to white society by initially accepting Anglo-American practices and later modifying them to conform to tribal traditions.

This selective assimilation of Anglo-American customs is best illustrated by the authors' description of tribal courts. Here they demonstrate that most often the Native American judge's personal involvement plays a much greater role in the tribal court system than does the presence of attornies who, at best, take a passive role when they participate at all. Since the goal of justice in the Indian community is to avoid social tension and quarrels rather than to punish (as in the white world), the judge assumes the role of mediator-a position traditionally held by tribal chiefs.

The authors depend on specific pieces of legislation and on the 
decisions of federal courts in cases involving Indians for their major sources of information. Although their descriptions of legal cases are frequently confusing, the fault lies not with the authors but instead with the ambiguous nature of court decisions in general and with the federal courts' ambivalent attitudes toward Indian rights in particular. While Deloria and Lytle are unable to present decisive proof that Marshall's "domestic dependent nation" dictum is the standard guide for American jurists, they present a provocative case for their contention that Marshall's concept can be traced through many subsequent legislative and judicial acts.

American Indians, American Justice is an interesting analysis of the constitutional basis for Native American rights and United StatesIndian relations. It should be required reading not only for scholars of American Indian studies, but also for students of United States constitutional history as well.

Texas Christian University

THOMAS F. SCHILZ

Black Southerners, 1619-1869, by John B. Boles. Lexington: University Press of Kentucky, 1983. xi, 244 pp. Bibliographic essay, index. $\$ 24.00$ cloth.

Few aspects of American history have received more attention than the institution of slavery. Some of our best and some of our worst historical writing has dealt with the peculiar institution, but several areas of sharp disagreement still remain. Anyone who wishes to be knowledgeable about the current status of scholarship in this field can read either the voluminous literature or this exceptionally fine summary by John B. Boles, professor of history at Rice University and editor of the Journal of Southern History. Anyone who approaches the literature will do well to be guided by his twenty-six page bibliographical essay.

In lucid, readable prose, the author has packed a surprising amount of information in a relatively brief volume as he tells the story of black southerners from the pre-American background to 1869. Neither blacks nor whites can be understood in the South, he asserts, without taking the other into account, for "southerner is a biracial term" $(x)$. There is room here to mention only a few of his observations. The colonial slave trade reached its peak between about 1740 and 1760 , with the middle passage death rate being almost the same as that for white immigrants in the seventeenth century. An unusual aspect of American slavery was its rapid growth from natural increase, thus making extensive importation unnecessary. 
Copyright of Annals of Iowa is the property of State of Iowa, by \& through the State Historical Society of Iowa and its content may not be copied or emailed to multiple sites or posted to a listserv without the copyright holder's express written permission. However, users may print, download, or email articles for individual use. 